\title{
Assessment of Recent Tectonic Activity along the Yamuna Basin, Garhwal Region, NW-Himalaya, India: Based on Morphotectonic Analysis
}

\author{
Prerna Gahlaut $^{1^{*}}$ (D), Ramesh Chandra Patel2, Ramamoorthy Ayyamperumal ${ }^{3}$, Madhusudan Sati1, \\ Dinesh Chandra Nainwal ${ }^{\#}$
}

${ }^{1}$ Department of Geology, H.N.B. Garhwal University, Srinagar, India

${ }^{2}$ Department of Geology, Banaras Hindu University, Varanasi, India

${ }^{3}$ MOE Key Laboratory of Western China's Environmental System, College of Earth and Environmental Sciences, Lanzhou

University, Lanzhou, China

${ }^{4}$ SDM Government Post Graduate College Affiliated by SDSUV, Dehradun, India

Email: *prernagahlaut93@gmail.com

How to cite this paper: Gahlaut, P., Patel, R.C., Ayyamperumal, R., Sati, M. and Nainwal, D.C. (2021) Assessment of Recent Tectonic Activity along the Yamuna Basin, Garhwal Region, NW-Himalaya, India: Based on Morphotectonic Analysis. Open Journal of Geology, 11, 734-755.

https://doi.org/10.4236/ojg.2021.1112036

Received: February 26, 2021

Accepted: December 28, 2021

Published: December 31, 2021

Copyright $\odot 2021$ by author(s) and Scientific Research Publishing Inc. This work is licensed under the Creative Commons Attribution International License (CC BY 4.0).

http://creativecommons.org/licenses/by/4.0/

\section{(c) (i) Open Access}

\begin{abstract}
Decoupling between climate and tectonics, transform the elevation of earth surface regionally by denudation and displacement of land. To extract the tectonic footprints on morphology of landform, geormophometry is widely accepted tool due to visible responses in Drainage architecture to an intense tectonic environment. The present morphology of Yamuna basin in the Garhwal Himalaya, India is a result of continuing crustal deformation; erosion and deposition in the area. The drainage system and geomorphic expression of topography have been significantly influenced by active tectonics in this basin. In present study, for numerical modelling to detect the influence of tectonic signals on landform, we used morphotectonic parameters, to gradient index (SL), valley floor height to width ratio (Vf), asymmetry factor (Af), basin shape index (BS) and hypsometric integral (HI), extracted from SRTM DEM with resolution of $30 \mathrm{~m}$. All these morphotectonic parameters are integrated to produce an index of relative active tectonics (IRAT). The Yamuna basin is classified into three groups based on IRAT, very high $(<2.0)$; moderate $(2.0-2.25)$ and low $(>2.25)$ based on the degree of tectonic activity. Result shows approx. 56\% of Yamuna basin experience high tectonic activity. This along strike deformation pattern pronouncedly emulates subsurface geometry based tectonic model.
\end{abstract}

${ }^{*}$ Corresponding author

"Directorate of Higher education, Regional Office, Dun University Campus, Dehradun, Uttarakhand. 


\section{Keywords}

Active Tectonics, Landform Evolution, Morphotectonic Parameters,

Landslide, IRAT

\section{Introduction}

Geometry of landscape is the combined product of interaction between endogenic and exogenic earth processes. Substantial set of recent documentation with sophisticated statistical and analog models have used to replicate dynamic interchange between subsurface crustal distortion and exogenic erosional processes as the root of landform evolution. A debate has initiated with this to elucidate whether exogenic denudation along with tectonic mechanism is equally in charge or it is has relegate control over unloading of landmass [1] [2]. Tectonic geomorphology outlines the understanding of robust impact of global tectonics with multi-layered spatio-temporal development of landscape [3]-[8]. The most common approach to accomplish confined influence of tectonic movement is depend on comparative relation between denudational chronologies with thermal histories of rock however palaeoelevation with reference to long term fluctuation in sea level are not completely involved in framework so far. Digital Elevation Model (DEM) is also extensively adopted digital technique to visualize topographic map. The essential purpose of DEMs in tectonic geomorphology is mathematical quantification of landscape morphology to build the immediate numerical model of surface response with ongoing subsurface movement as it permit to real-time mapping of topography and tectonic induced surface deformation without limitation of spatial scale.

In an orogeny, contoured by the dichotomy of lithospheric adjustment and precipitation, fluvial system is among the crucial exogenic agents to shape montane landforms. Land mass distribution in high elevated area is dominantly hinge on the mechanical characteristics of rock formation and spatial distribution-geometry of drainage network. Mountainous Drainage pattern is vigorously susceptible to mechanisms such as folding, faulting and basin tilting and fluvial mechanics such as river incision and sediment load [9] [10]. In Himalaya, compressional regime provides continuous accretionary influx by varied crustal shortening along thrust boundaries hence results in heterogeneity in spatial distribution of upliftment rates [11]-[17]. These chronological datasets synchronised well with subsurface geometry of Main Himalayan Décollement [18]. While present day precipitation in Himalaya is more dynamic in southern front along with orographic barriers inference more vibrant geomorphological characteristics in central part in north of convergent mountain belt [8] [15] [19] [20] [21] [22]. Morphometric parameter and geomorphic indices of drainage network have been used for identification and categorization of these active zones [23].

Yamuna is the largest tributary of Ganga and flow across the strike of the 
structurally complex, deformed and tectonically unstable fold-thrust belt of NW Himalaya, in Uttarakhand and its catchment area falls into "Zone 4" in India's seismic hazard zoning map. Present investigation is analysed spatial heterogeneity of landmass distribution with use of six morphotectonic indices comprised of stream length gradient index (SL), valley floor width to height ratio (Vf), hypsometric integral $(\mathrm{HI})$, basin shape index $\left(\mathrm{B}_{\mathrm{S}}\right)$, and basin asymmetry factor ( $\mathrm{Af}$ ) in Yamuna Basin Garhwal Area, NW-Himalaya (Figure 1(a) \& Figure 1(b)), Resulting model has been compared with published dataset [18] [24].

\section{Geological and Tectonic Setting}

\subsection{General Background}

Himalayan growth started around 50 Ma years ago, a continent-continent collision between Indian and Eurasian plates occurred along the Indus-Tsangpo Suture Zone (ITSZ) [25]. Subsequently, the Indian continent continued to converge under the Eurasian continent at a rate of $5 \mathrm{~cm} / \mathrm{yr}$ [26]-[32]. A fraction of this convergence is absorbed by crustal deformation of the northern margin of the Indian continent associated with the activation of several major thrust zones such as the synchronous Main Central Thrust (MCT) and South-Tibetan Detachment System (STDS), Main Boundary Thrust (MBT) and Main Frontal Thrust (MFT) (Figure 1(b)) [33]-[39]. The high-grade metamorphic units of the Higher Himalayan Crystalline (HHC) of Neoproterozoic age lie between the MCT and the STDS, and between the MCT and the MBT, the Paleoproterozoic to Paleozoic Lesser Himalayan meta-sedimentary (LHMS) zones are imbricated into a duplex and overlain by several klippen comprised of Neoproterozoic through Ordovician gneiss and high-grade metamorphic rocks of the HHC [40] [41] [42] [43]. Near the peak of the range, the north dipping STDS separates the HHC units to the south from the lower-grade Neoproterozoic-Eocene Tethyan Himalayan sequences (THS) to the north [44]. The sub-Himalaya consists of the Siwalik Hills which lies between the MBT and MFT [45]. The Indo-Gangetic foredeep formed in front of the rising Himalayan range where sediments eroded from the areas of high relief has been accumulated. North of the MFT, the décollement of the Indian basement (i.e. Main Himalayan Thrust: MHT) is thought to extend as a flat beneath the LHMS zones and to form a steeper ramp at the front of the HHC [46] [47] [48].

\subsection{Tectonostratigraphy Description of the Area in the Yamuna Basin}

The Yamuna basin comprises of the HHC, LHMS, Sub-Himalaya, and IndoGangetic alluvium (Figure 1(c)). The structurally highest tectonic zone in the north of the study area is the HHC. It is made up of the Vaikrita group which is characterized by high-grade metamorphic rocks and the Munsiari formation made up of low to medium grade metamorphic rocks (gneisses, meta basics, quartzite, and high-grade schist and granites). However, the rocks of the Vaikrita group and the THS are not exposed in the present study area in the Yamuna ba- 
sin. Structural window bound by MT comprises of the Ramgarh group and Berinag formation is exposed within the HHC at Kharsali [49]. Here, we name it as the Kharsali window (Figure 1(c)).

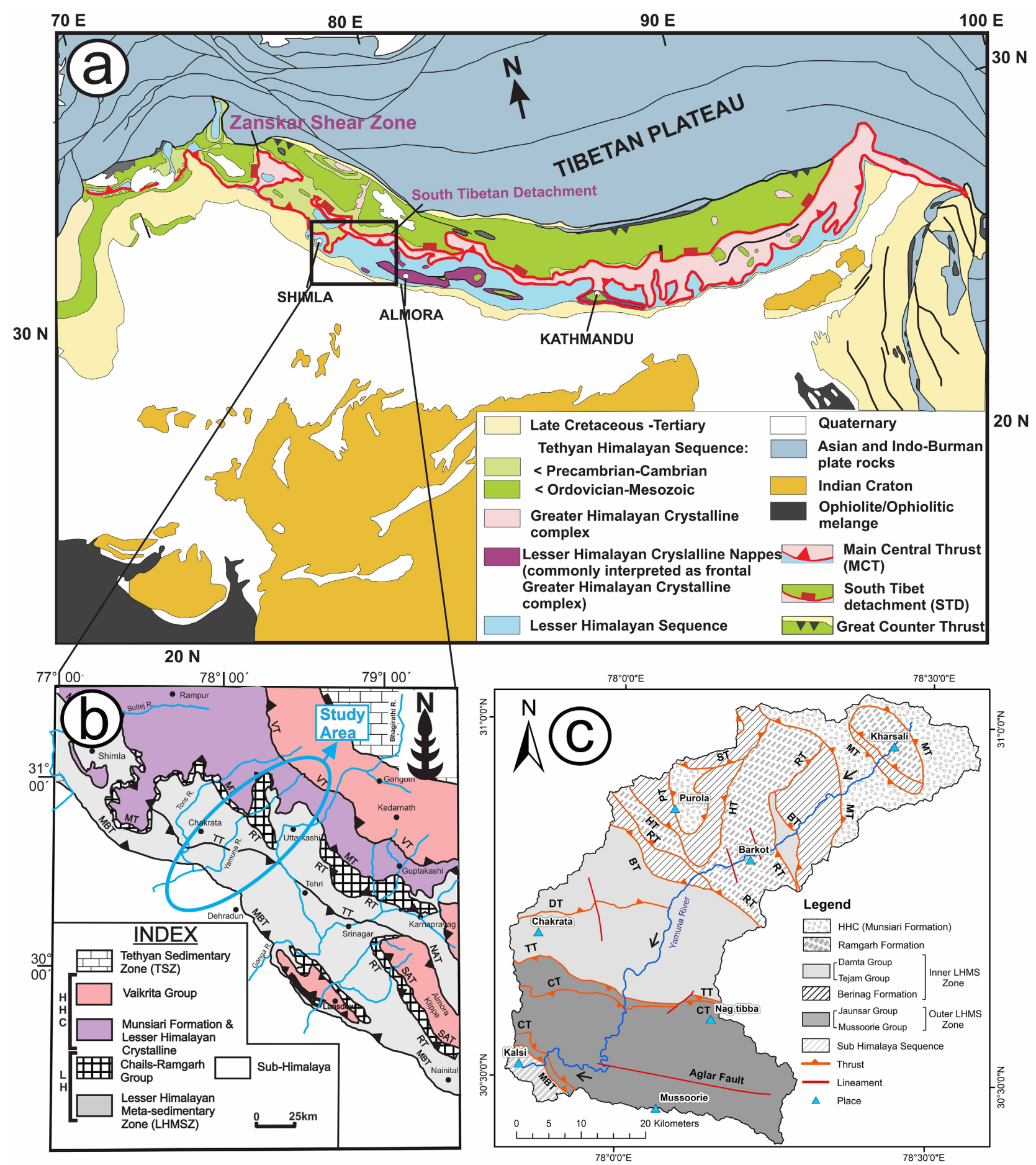

Figure 1. (a) Simplified geological map of Himalaya. (b) Location of study area in NW Himalaya with regional setup. VT (Vaikrita thrust), MT (Munsiari thrust), RT (Ramgarh thrust), TT (Tons Thrust), NAT (North almora thrust), SAT (South almora thrust) and MBT (Main boundary thrust) (c) Geological and structural framework of Yamuna basin. PT (Purola thrust), ST (Sandra thrust), HT (Hudoli thrust), BT (Berinag thrust), DT (Deoban thrust) and CT (Chandpur thrust); modified after [43] [49]. 
The footwall of the MT is covered by the LHMS zone; Ramgarh thrust sheet (RTS) and Purola klippe (Figure 1(c)). The RTS is made up of the Ramgarh group which is separated from the Inner LHMS sequence along the Ramgarh Thrust (RT). The Purola klippe represents an un-eroded part of the HHC which was once thrust over the Inner LHMS sequence along the Purola Thrust (PT). The PT represents a southward extension of the MT [49] [50]. The local structural breaks are the Sandra Thrust (ST) and Hudoli Thrust (HT). In the footwall of the MT, the LHMS zone is classified into a vast window of Inner LHMS sequence and Krol nappe of Outer LHMS sequence. Stratigraphic subdivisions of Inner LHMS are made up of dolomites, carbonaceous slates and carbonates while the outer LHMS sequence is characterized by slate, quartzite, conglomerate and limestone [43]. Both Inner and Outer LHMS sequences are separated by south-dipping Tons Thrust (TT). Krol nappe is synclinorium in nature and it is cutting across by major E-W trending strike-slip fault which is named the Aglar fault [49]. The LHMS sequence in this area is separated from the sub-Himalaya along with the NE-dipping MBT. Southernmost Indo-Gangetic Alluvium in the study area is separated from the sub-Himalaya along the HFT.

\subsection{Active Structures}

An active zone along the MCT has been described in the NW-Himalaya based on the concentration of micro-seismicity [51]-[58] and low-temperature thermochronological cooling ages [58] [59] [60] [61] [62]. Similarly, differential rock uplift inferred across the PT2 in the Nepal Himalaya studying uplift of river terraces [37], geodetically determined uplift rates [32] and elevated electrical conductivity [63]. Receiver function study shows the presence of the active MHT décollement below the Himalaya [51]. It is characterized by a flat beneath the LHMS sequence and northward dipping mid-crustal ramp located approximately beneath the physiographic boundary between the LHMS sequence and the HHC [52] [58]. This inferred flat and mid-crustal ramp, although varying somewhat along strike in its location and dip [32] [58] [64], is responsible for differential rock uplift which causes changes in modern geomorphology and spatial patterns of denudation rates [65] [66]. The differential rock uplift inferred across the MCT zone could be produced by one or combination of the followings scenarios: 1) passive over thrusting across the MHT ramp with no additional out-of-sequence deformation [67], 2) an emergent thrust fault located at the PT2 that is not currently mapped at the surface [65] [68], and/or 3) an actively growing blind duplex on MHT ramp [58] [69] [70].

\section{Methodology and Materials}

For the present assessment of morphometric analysis along the Yamuna basin, all morphotectonic parameters are calculated using SRTM DEM with a spatial resolution of 30 meters. The Yamuna basin is subdivided into 16 sub-basins using the [71], (Figure 2) stream ordering principle. To understand the impact of 

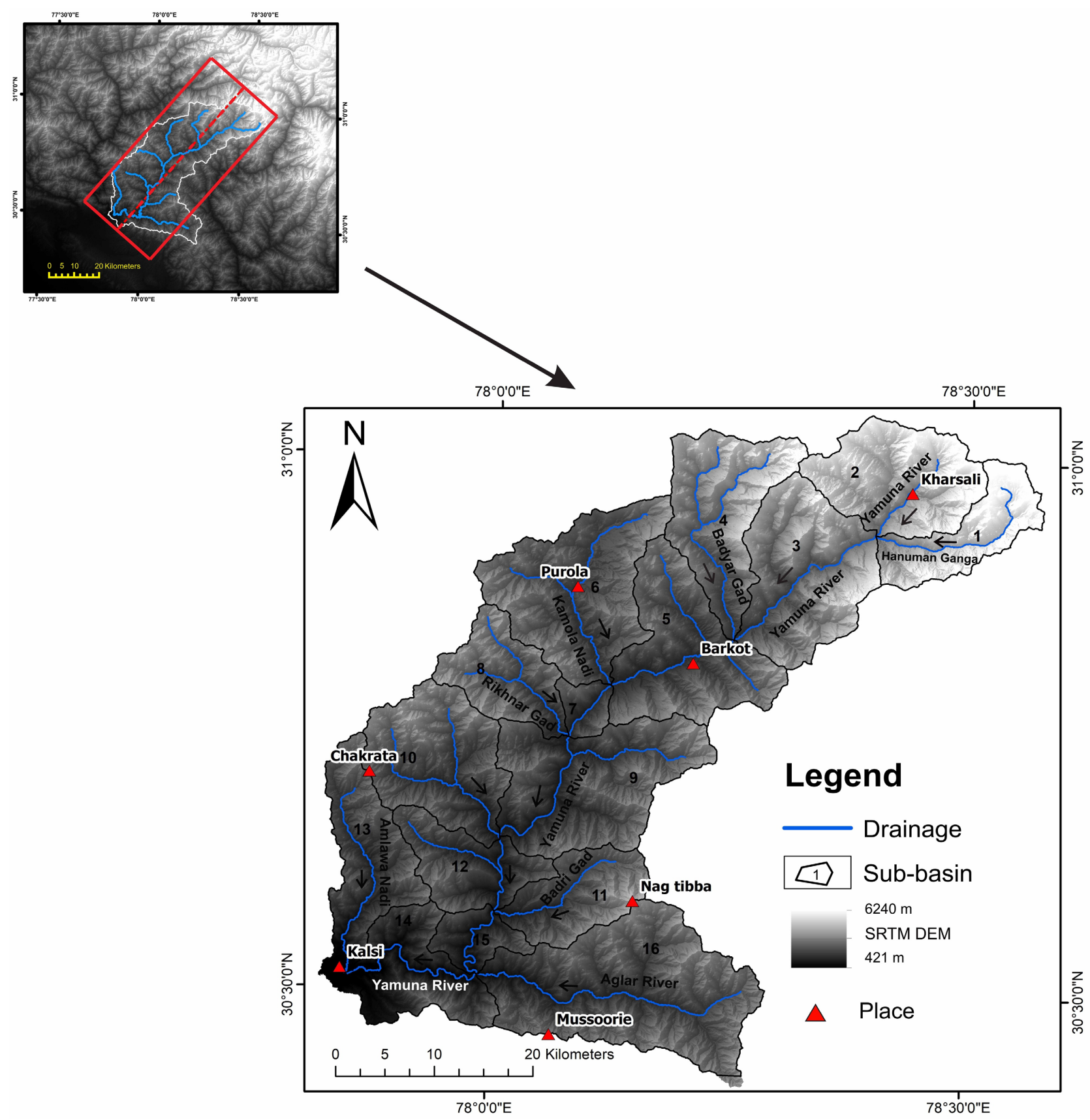

Figure 2. Drainage of Yamuna River and its major tributaries and reference numbers of six sub-basins in Yamuna watershed. Rectangle in red is for swath profile in Figure 8(b).

tectonic activity on regional morphology, it is more necessary to study a smaller region. The smaller regions respond to morphotectonic changes due to their low stream power [72]. Seven morphometric parameters have been calculated to capture active-tectonic variation in the region. These parameters include stream length gradient index (SL), valley floor width to valley height ratio (Vf), basin shape index $\left(\mathrm{B}_{\mathrm{S}}\right)$, basin asymmetry factor (Af), and hypsometric integral (HI) (Table 1). All these parameters are integrated to derive the Index of relative active tectonics (IRAT). The IRAT is further subdivided into four classes based on 
the intensity of relative tectonic activity. All these SRTM DEM derived parameters have been carried out in the ArcGIS 10.2 platform. Along with the morphotectonic analysis, seismicity of the Yamuna basin is also considered to validate its relevance with tectonic activity. The seismicity map of the Yamuna basin has been prepared by collecting earthquake data from the ISC catalog (1911-2019) and published a seismicity map [56]. Across the Yamuna basin, the seismic belt passes along a zone between Barkot and Kharsali, which is cutting across by many faults such as the MT, BT, RT, HT, and PT. The susceptibility status of the landslide in the Yamuna basin has been studied recently using different geomorphological factors [24]. These data are also integrated to validate its relevance with active tectonics.

Table 1. Mathematical expression of morphotectonic parameter, with their categorized classes.

\begin{tabular}{|c|c|c|c|}
\hline Morphotectonic parameter & Mathematical expression & Classes & References \\
\hline $\begin{array}{l}\text { Stream Length Gradient } \\
\text { Index }(\mathrm{SL})\end{array}$ & $\begin{array}{l}\qquad \mathrm{SL}=(\Delta \mathrm{H} / \Delta \mathrm{Lr}) \mathrm{Lt} \\
\text { where, } \Delta \mathrm{H} \text { is change in altitude, } \Delta \mathrm{Lr} \text { is the length of a reach, } \\
\text { and } \mathrm{Lt} \text { is the horizontal distance from the watershed divide to } \\
\text { the centre of the reach }\end{array}$ & $\begin{array}{c}\text { Class } 1 \\
(>500) \\
\text { Class } 2 \\
(500-300) \\
\text { Class } 3 \\
(<300)\end{array}$ & Hack (1973) \\
\hline $\begin{array}{l}\text { Valley floor width-to-height } \\
\text { ratio (Vf) }\end{array}$ & $\begin{array}{l}\qquad \mathrm{Vf}=2\left\{\mathrm{~V}_{\mathrm{fw}} /\left(\mathrm{E}_{\mathrm{ld}}+\mathrm{E}_{\mathrm{rd}}-2 \mathrm{E}_{\mathrm{sc}}\right)\right\} \\
\text { where, } \mathrm{V}_{\mathrm{fw}} \text { is the width of the valley floor, } \mathrm{E}_{\mathrm{ld}} \text { and } \mathrm{E}_{\mathrm{rd}} \text { are } \\
\text { elevations of the left and right valley divides (facing downstream) } \\
\text { respectively, and } \mathrm{E}_{\mathrm{sc}} \text { is the elevation of the valley floor. }\end{array}$ & $\begin{array}{c}\text { Class } 1 \\
(<0.5) \\
\text { Class } 2 \\
(0.5-1.0) \\
\text { Class } 3 \\
(\geq 1)\end{array}$ & $\begin{array}{c}\text { Bull and } \\
\text { McFadden, } 1977\end{array}$ \\
\hline $\begin{array}{c}\text { Drainage basin } \\
\text { asymmetry factor (Af) }\end{array}$ & $\begin{array}{l}\qquad A f=100\left(A_{r} / A_{t}\right) \\
\text { where } A_{r} \text { is the area of the basin to the right (downstream) } \\
\text { of the trunk rivulet, } A_{t} \text { is the total area of the drainage basin }\end{array}$ & $\begin{array}{c}\text { Class } 1 \\
(>15) \\
\text { Class } 2 \\
(5-15) \\
\text { Class } 3 \\
(<5)\end{array}$ & $\begin{array}{l}\text { Hare and } \\
\text { Gardner, 1985; } \\
\text { Keller and } \\
\text { Pinter, } 2002\end{array}$ \\
\hline Hypsometric integral (HI) & $\begin{aligned} & \mathrm{HI}=\left(\mathrm{E}_{\mathrm{L}} \text { avg }-\mathrm{E}_{\mathrm{L}} \min \right) /\left(\mathrm{E}_{\mathrm{L}} \max -\mathrm{E}_{\mathrm{L}} \min \right) \\
& \text { where, } \mathrm{E}_{\mathrm{L}} \text { avg }=\text { average elevation, } \mathrm{E}_{\mathrm{L}} \min =\text { minimum elevation, } \\
& \mathrm{E}_{\mathrm{L}} \max =\text { maximum elevation. }\end{aligned}$ & $\begin{array}{c}\text { Class } 1 \\
(>0.47) \\
\text { Class } 2 \\
(0.46-0.47) \\
\text { Class } 3 \\
(<0.46)\end{array}$ & $\begin{array}{l}\text { Strahler, 1952; } \\
\text { Keller and } \\
\text { Pinter, } 2002\end{array}$ \\
\hline Basin shape index (Bs) & $\begin{array}{l}\qquad B_{S}=B_{L} / B_{w} \\
\text { where } B_{L} \text { is the length of a basin and it is measured from the } \\
\text { head point to the mouth, and } B_{W} \text { is the width of a basin and is } \\
\text { measured at widest point of the basin. }\end{array}$ & $\begin{array}{c}\text { Class } 1 \\
(>1.76) \\
\text { Class } 2 \\
(1.11-1.76) \\
\text { Class } 3 \\
(<1.11)\end{array}$ & $\begin{array}{l}\text { Bull and } \\
\text { McFadden, } \\
\text { 1977; } \\
\text { Ramirez- } \\
\text { Herrera, } 1998\end{array}$ \\
\hline
\end{tabular}




\section{Result}

\subsection{Spatial Distribution of Morphotectonic Parameters}

Morphotectonic is used to calculate tectonic activity in terms of mathematical expression (Table 1). SL index is controlled by crustal movement and rock strength. Sub-basins 1, 4, and 13 fall in class- 1 type due to the high value of SL index while other sub-basins such as $2,3,6,8,10,11$, and 16 belong to class-2 type with moderate SL index values (Figure 3(a)). The highest values of SL in the Yamuna basin are $>5000$ in sub-basin 4 and peaks of SL index values in sub-basin 1 are 2808.11, 2925.61, and 4092.86 and sub-basin 13 are between 6000 - 2000 (Figure 3(b)). Sub basins those falls in class 2 have average a value of SL index varies from 485.5 to 328 . The lowest average values are $50-100$ and are calculated in sub-basins $5,7,9,12,14$, and 15 .

The area of active uplift is linked up with continued down cutting in rivulets that characterized $\mathrm{V}$-shaped valleys illustrate the low value of $\mathrm{Vf}(\mathrm{Vf}<1)$ while $\mathrm{U}$-shaped flat-floored valleys ( $\mathrm{Vf}>1$ ) show an accomplishment of the base level of erosion prominently in reply to respective tectonic dormancy [23] [73]. 11 sub-basins out of 16 falls in class 1 of $\mathrm{Vf}(\mathrm{Vf}<0.5)$. Sub-basin 8, 9, and 10 are in class 2, and sub-basin 14 and 15 are in class 3 with the highest values of $\mathrm{Vf}$ (Figure 4(a)). The spatial distribution of Af (Figure 4(b)) values is quite the opposite of that of Vf. Only 5 sub-basins (no. 1, 9, 11, 12, and 13) Value of Af is relatively very high in sub-basins $1,9,11,12$, and 13 and fall in class- 1 type. Major tributaries in this sub-basin are tilting in $\mathrm{W}$ to NW direction. The highest tilting is recorded in sub-basin 12 (Af < 27). 10 sub-basins $(62 \%$ of the total catchment area) are in class 2 with moderate tilting. Only sub-basin 15 is in class 3 (Af $\sim 3$ ).

Like Vf, sub-basin 1, 2 from upper catchment region (HI 0.49 and 0.48 respectively) and in the lower half of Yamuna basin, sub-basin 8, 10, 12, 13 and 16 belong to class 1 of HI (Table 2). The hypsometric curve of Hanuman Ganga valley (sub-basin 1) is S-shaped (concave upward and convex in downward) an indication of a transition stage between youth to mature, the upper part of $\mathrm{HI}$ curve of this tributary is in distorted or monadnock phase, while the lower section is still in in-equilibrium or young stage (Figure $5(\mathrm{a})$ ). With HI $\sim 0.46$, sub-basin 11 falls in class 2 . Sub-basins 3, 5, 7, 9, 14 and 15 falls in class 3 (Table 2) with very low HI values i.e. $<0.42$ (Figure $5(b)$ ). Basin shape index $\left(B_{s}\right)$ is an identical feature of a watershed that is controlled by surface to subsurface processes. $B_{S}$ ranges in between 0.51 (sub-basin 12) to 2.39 (sub-basin 13) in focused area. The majority of the sub-basins in the Yamuna basin, fall in classes 1 and 2, with elongation in shape and higher $\mathrm{B}_{\mathrm{S}}$ values as compared to class 3 , which has circular shaped sub-basins with low $B_{S}$ values. Sub-basin $1,4,11,13$, and 16 are elongated in shape and show the highest value of $B_{S}$ among all sub-basins (Figure 6(a)). While in the case of sub-basins 5, 7, 9, 12, and 15, elongated valley transforms into circular one with very low $B_{S}$ values (Bs $\sim 0.99$ to 0.51 ). 
(a)
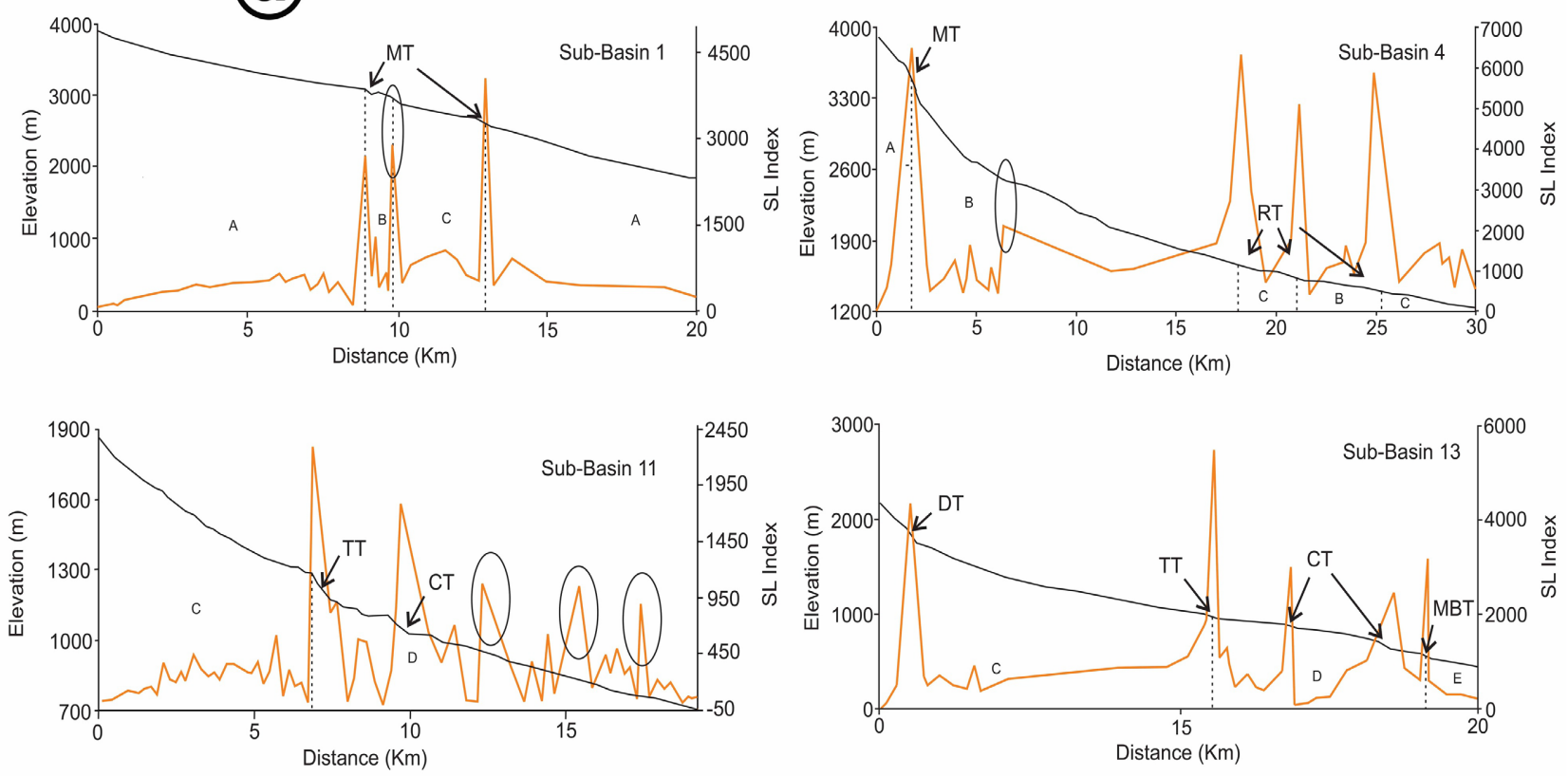

Longitudinal River Profile SL Index

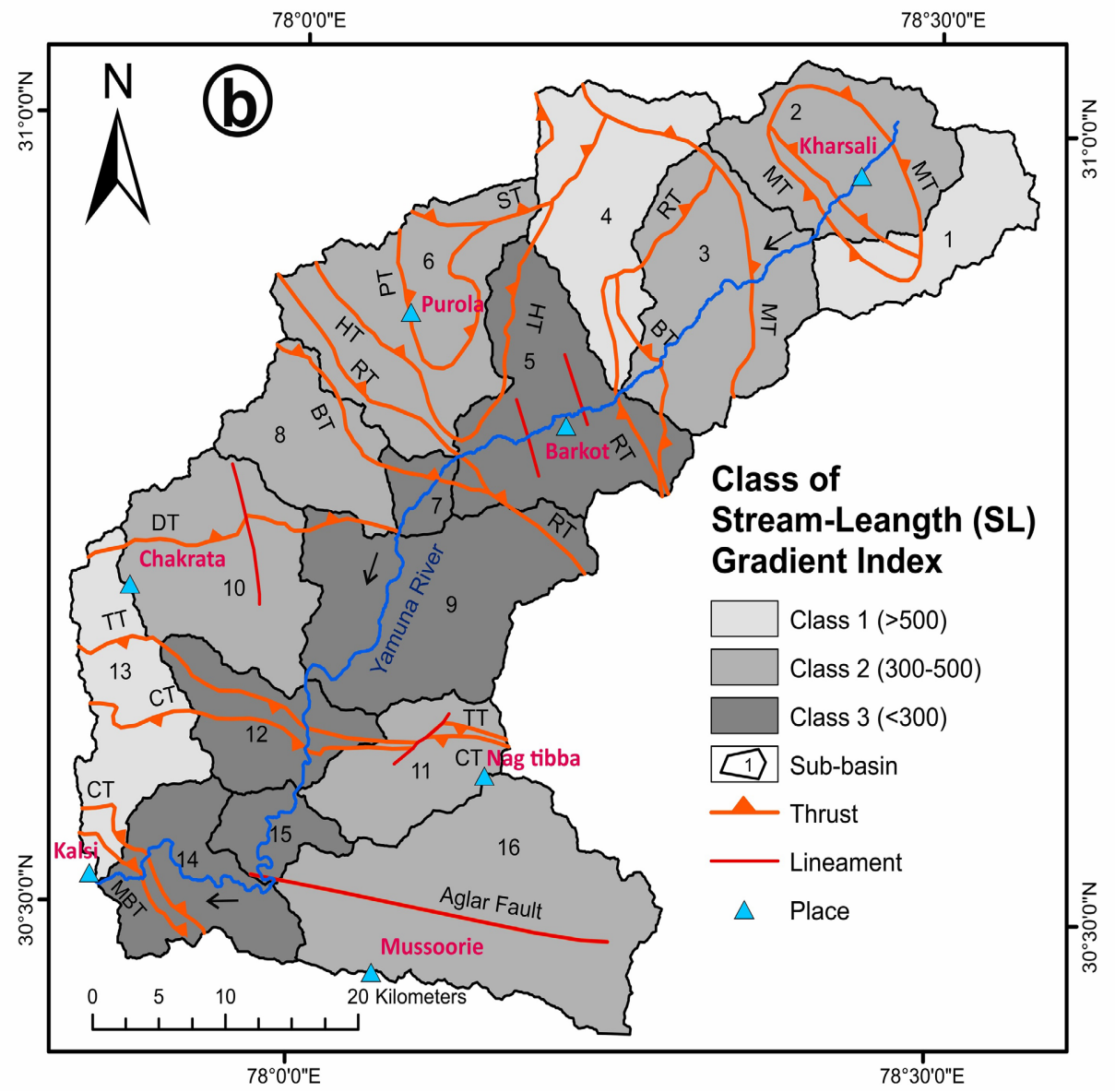

Figure 3. (a) Example of longitudinal river profile and SL graph of sub-basin 1, 4, 11, and 13. (A-Munsiari Formation, B-Ramgarh Formation, C-Inner LHMS sequence, D-Outer LHMS sequence and E-SHS). (b) Classes of SL gradient index in Yamuna basin. 

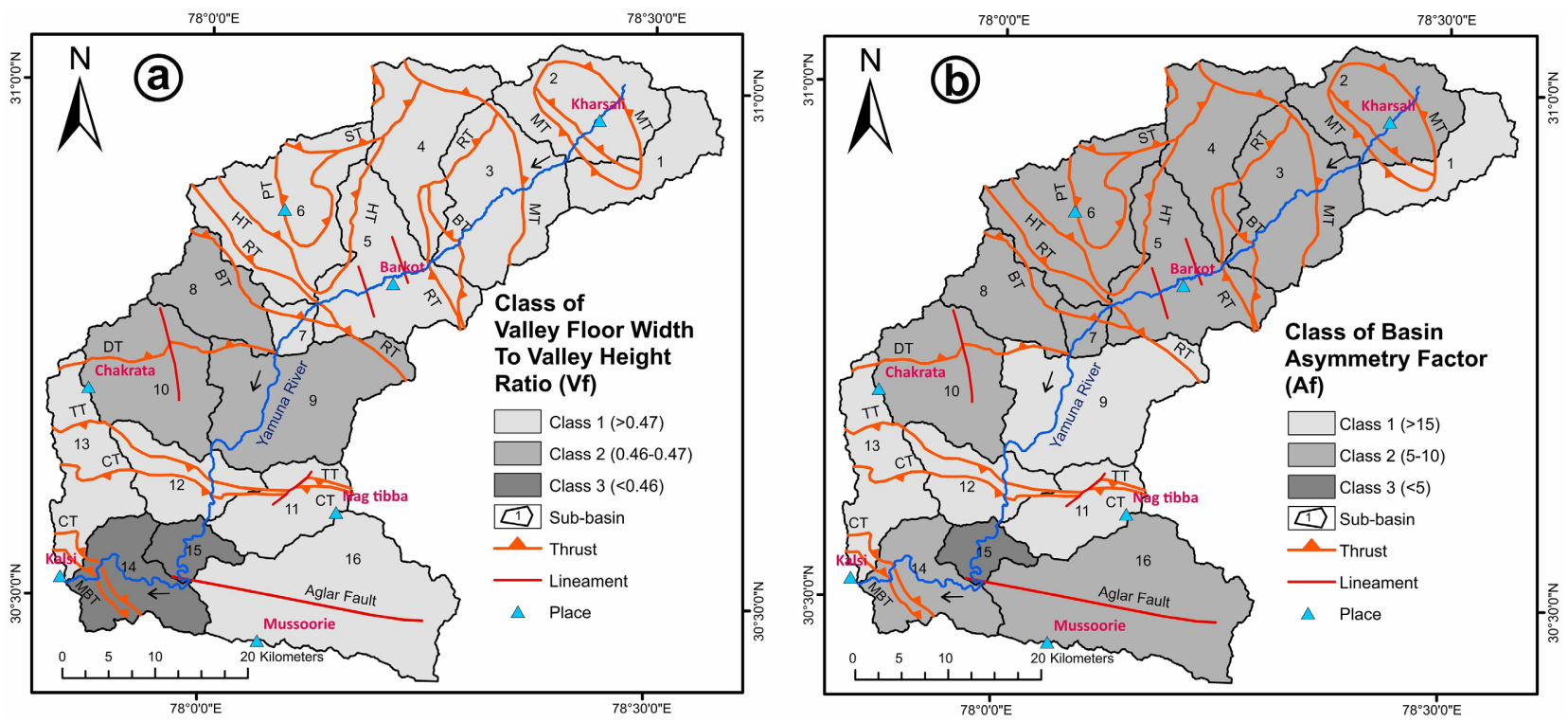

Figure 4. (a) Classes of Vf for Yamuna basin. (b) Classes of AF for Yamuna basin.

Table 2. Calculated classes of all morphotectonic parameters in each sub-basin with IRAT classes and respective tectonic activity.

\begin{tabular}{|c|c|c|c|c|c|c|c|c|}
\hline basin no. & Af- 50 & Vf & SL index & BS & $\mathrm{HI}$ & IRAT value & IRAT class & Activity \\
\hline 1 & 1 & 1 & 1 & 1 & 1 & 1 & 1 & Highly active \\
\hline 2 & 2 & 1 & 2 & 3 & 1 & 1.8 & 1 & Highly active \\
\hline 3 & 2 & 1 & 2 & 2 & 3 & 1.8 & 1 & Highly active \\
\hline 4 & 2 & 1 & 1 & 1 & 3 & 1.2 & 1 & Highly active \\
\hline 5 & 2 & 1 & 3 & 3 & 3 & 2.2 & 2 & $\begin{array}{c}\text { Moderately } \\
\text { active }\end{array}$ \\
\hline 6 & 2 & 1 & 2 & 2 & 3 & 2 & 2 & Highly active \\
\hline 7 & 2 & 1 & 3 & 3 & 3 & 2.2 & 2 & $\begin{array}{c}\text { Moderately } \\
\text { active }\end{array}$ \\
\hline 8 & 2 & 2 & 2 & 2 & 1 & 2 & 2 & $\begin{array}{c}\text { Moderately } \\
\text { active }\end{array}$ \\
\hline 9 & 1 & 2 & 3 & 3 & 3 & 2.4 & 3 & Less active \\
\hline 10 & 2 & 2 & 2 & 2 & 1 & 2 & 2 & $\begin{array}{c}\text { Moderately } \\
\text { active }\end{array}$ \\
\hline 11 & 1 & 1 & 2 & 1 & 2 & 1.4 & 1 & Highly active \\
\hline 12 & 1 & 1 & 3 & 3 & 1 & 1.8 & 1 & Highly active \\
\hline 13 & 1 & 1 & 1 & 1 & 1 & 1 & 1 & Highly active \\
\hline 14 & 2 & 3 & 3 & 2 & 3 & 2.4 & 2 & $\begin{array}{c}\text { Moderately } \\
\text { active }\end{array}$ \\
\hline 15 & 3 & 3 & 3 & 3 & 3 & 2.8 & 3 & Less active \\
\hline 16 & 2 & 1 & 2 & 1 & 1 & 1.4 & 1 & Highly active \\
\hline
\end{tabular}


(a)
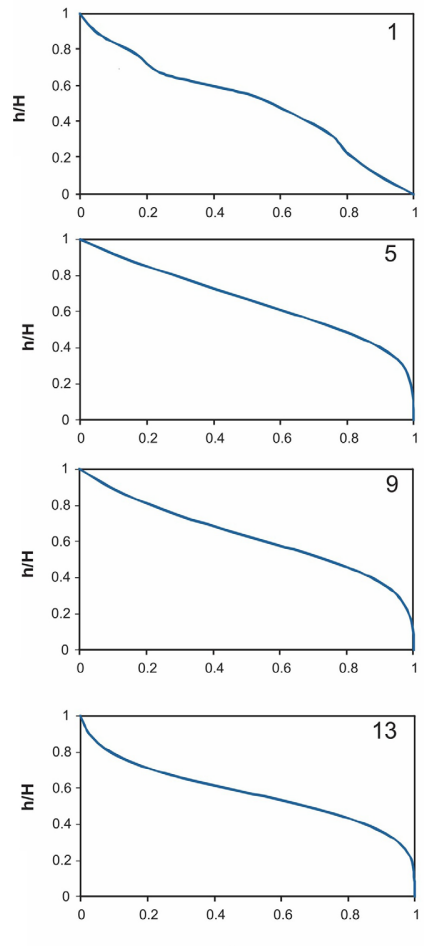

a/A
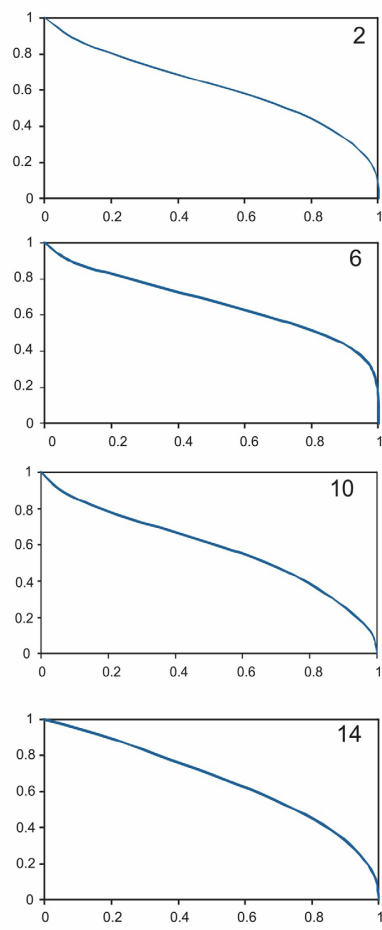
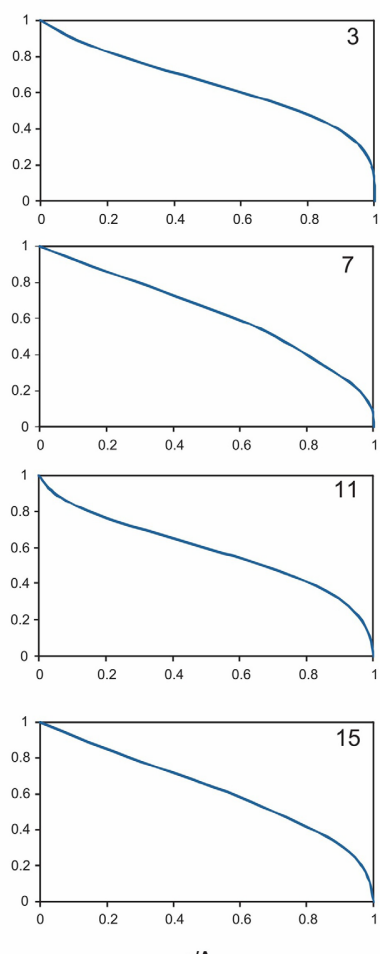

a/A
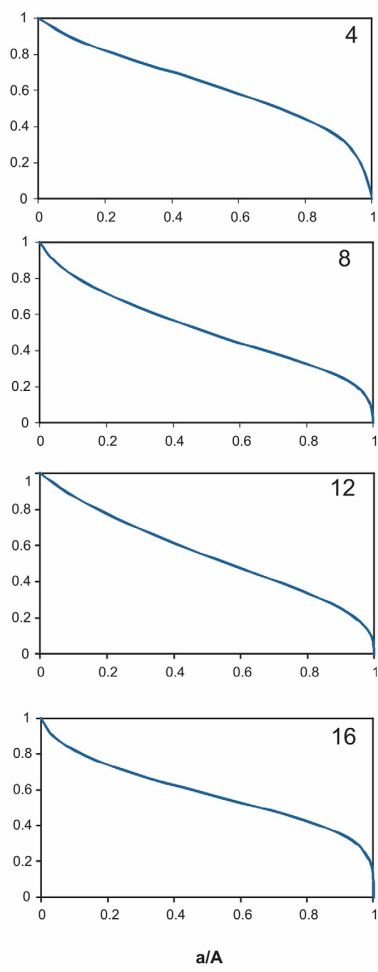

$\mathrm{a} / \mathrm{A}$

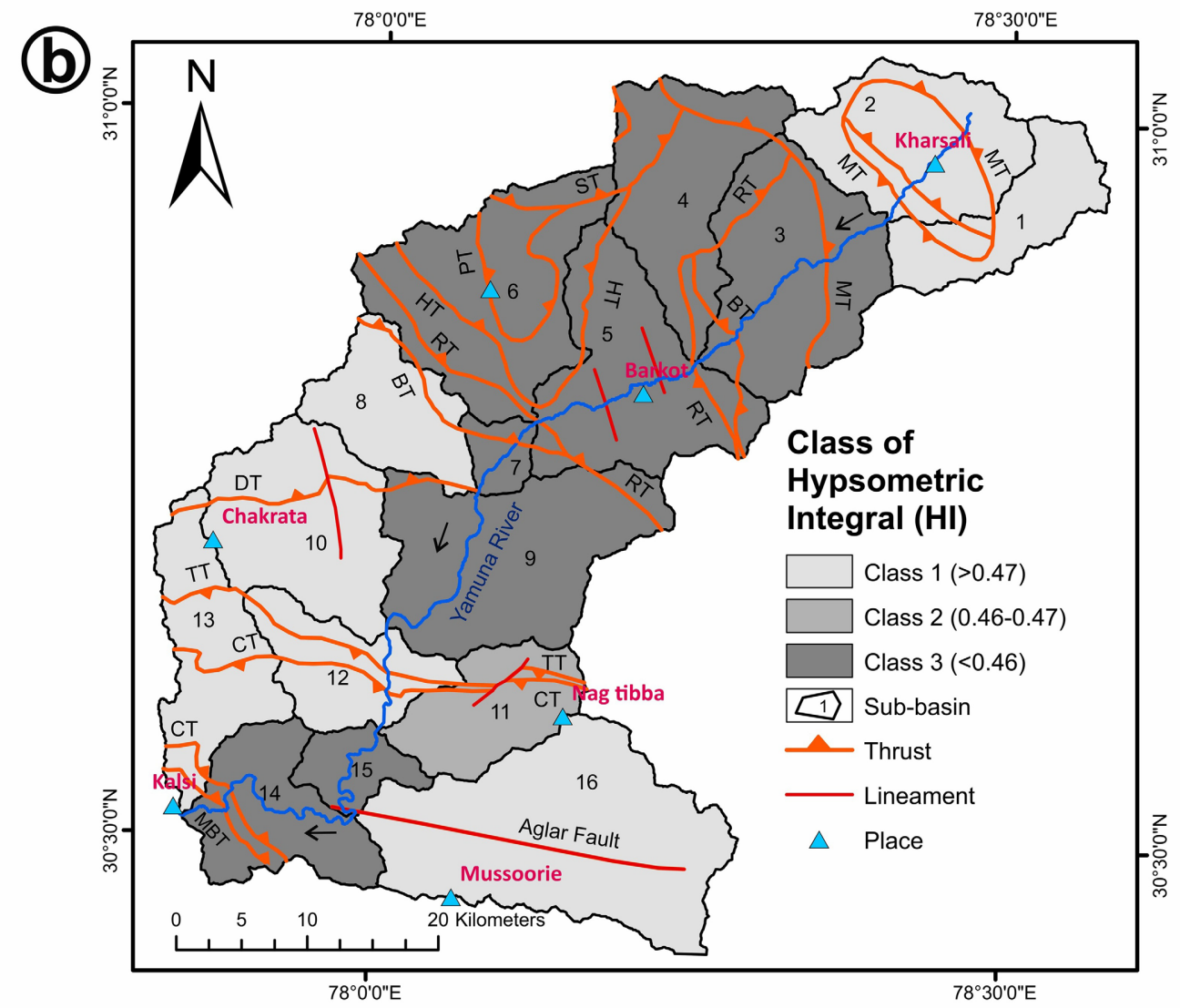

Figure 5. (a) Calculated HI curves in 16 sub-basins. (b) Classes of HI for Yamuna basin. 

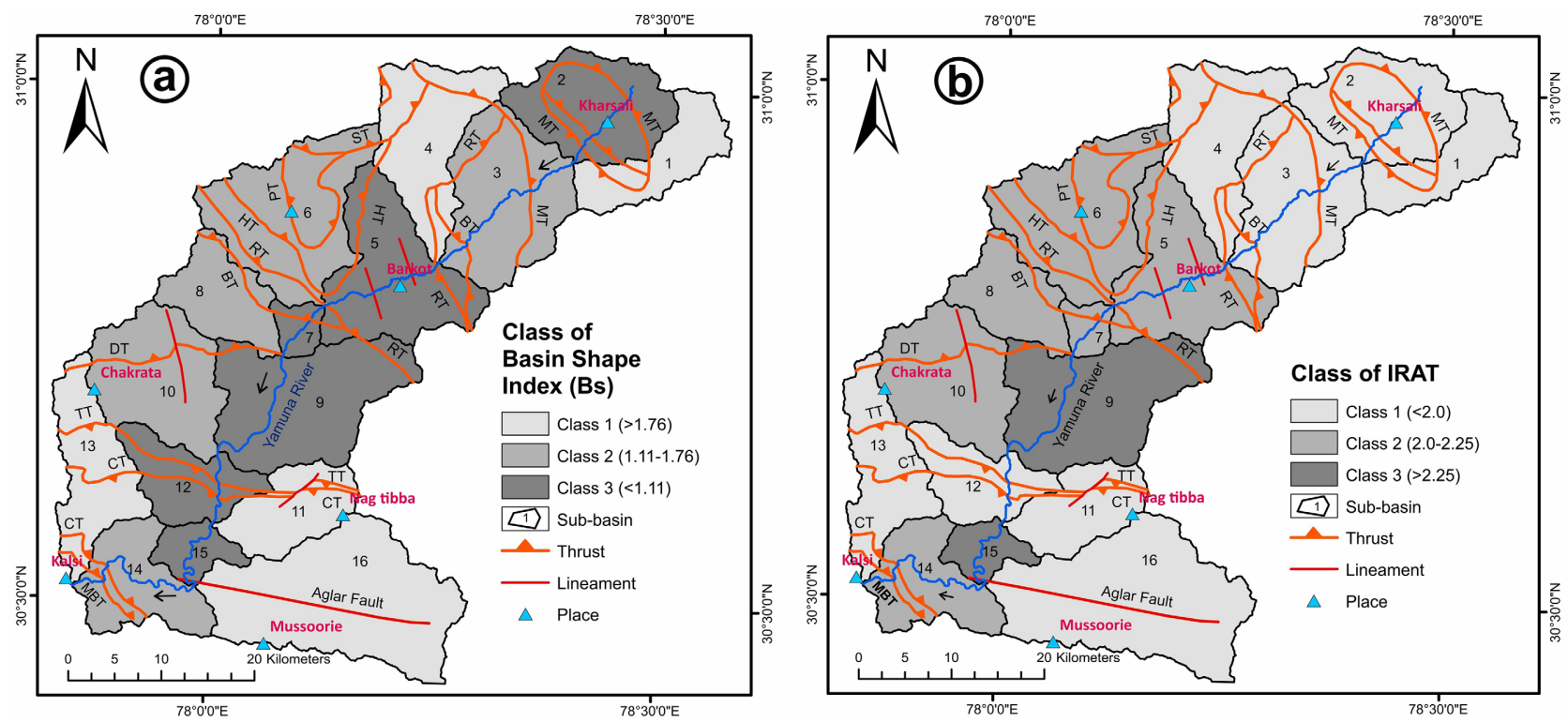

Figure 6. (a) Classes of $B_{S}$ for Yamuna basin. (b) Classes of IRAT of Yamuna basin.

\subsection{Evaluation of Index of Relative Active Tectonics (IRAT)}

All these values of morphotectonic indices derived in the Yamuna basin are combined to extract the IRAT. The IRAT values are used to explain the spatial distribution of relative tectonic activity in the Yamuna basin. The values of IRAT have been grouped into three classes, Class-1 $(<2.0)$ highly active; class-2 $(2.0$ $2.25)$ moderately active and class-3 $(>2.25)$ represent less active basin respectively. In the present investigation of the study area, 56.25\% sub-basins which is 1375.218 sq. $\mathrm{km}$ of the study area belongs to class-1, while $31.25 \%$ sub-basins $\sim 268.11$ sq. $\mathrm{km}$ relates to class 2 and remaining $\sim 703.22 \mathrm{sq}$. $\mathrm{km}$ area which covers $12.5 \%$ sub-basins belongs to class 3 (Figure 6(b)).

\subsection{Seismicity and Landslide Occurrences in the Area}

The collision between Indian and Eurasian plates resulted in crustal shortening across the Garhwal and Kumaun Himalaya is $14 \mathrm{~mm} / \mathrm{yr}$ and $12 \mathrm{~mm} / \mathrm{yr}$, respectively [74]. From an average northward convergence rate of $\sim 50 \mathrm{~mm} / \mathrm{yr}$ of the Indian plate beneath the Tibetan plate, only $\sim 20 \mathrm{~mm} / \mathrm{yr}$ is being accommodated [28] and retains the complete Himalaya seismically active. An independent outlook of seismically and tectonically active structural framework of Himalaya is provided by seismic data. The seismicity map of the Yamuna basin has been prepared by collecting earthquake data from the ISC catalog (1911-2019) and published a seismicity map [56] (Figure 7(a)). The recorded history of this seismically active region presents an image with clustering of earthquake events of different magnitudes [40] [56] [58] [75], (Figure 7(a)).

Landslides are the natural phenomenon in the Himalayan mountain region. Landslides are erosive and accumulative processes that affect the geographical features of the drainage basin and for the determination of these characteristics, 

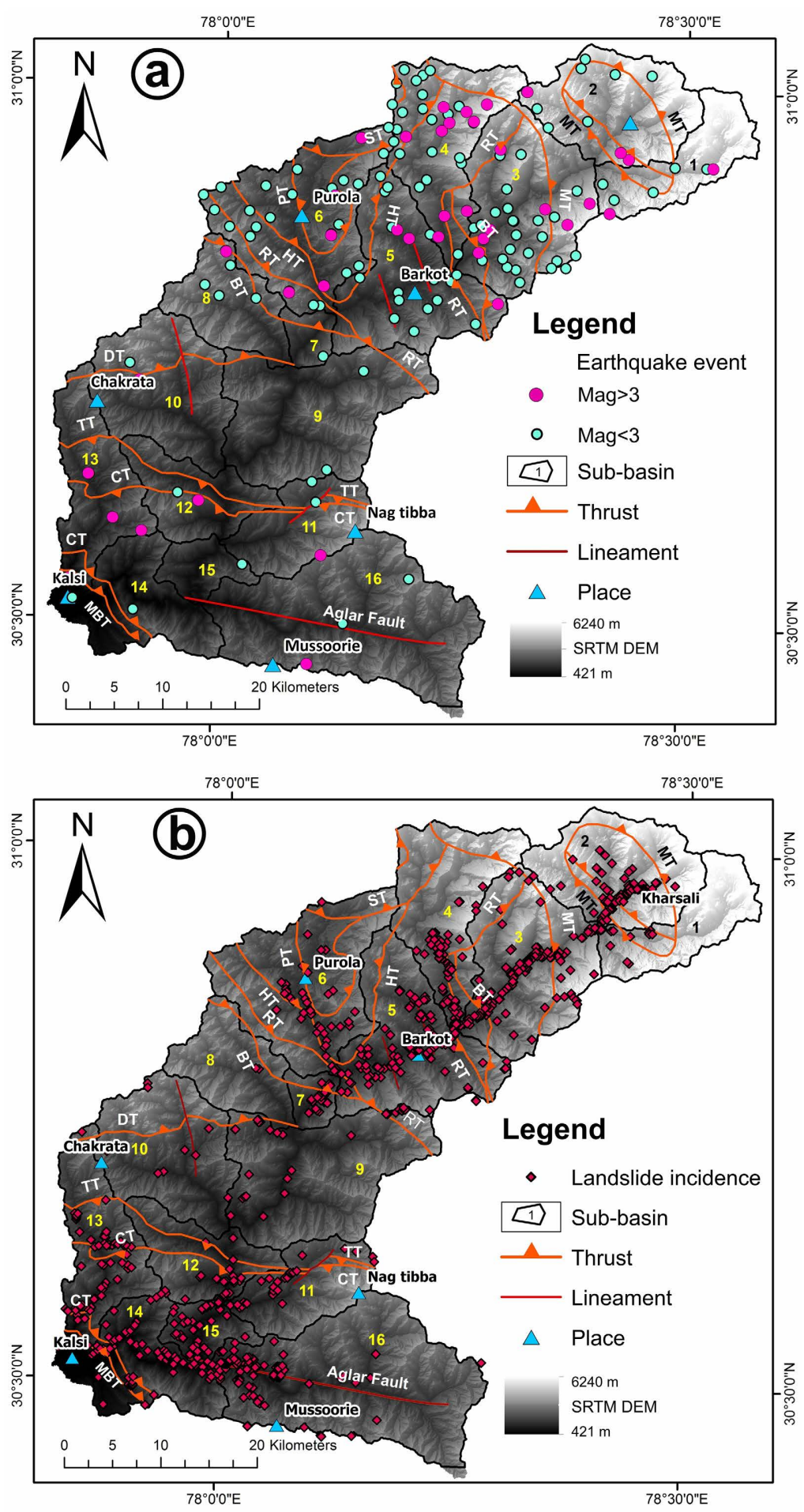

Figure 7. (a) Recorded earthquake events of different magnitude in Yamuna basin. (http://www.isc.ac.uk) (b) Distribution of landslides in Yamuna basin.

active tectonics turns to be a very important factor [23]. The influencing factors in the occurrence of landslide are tectonic activity, rainfall, lithology, and structural framework [76] [77] [78]. Tectonic processes that give rise to Himalaya are dominantly responsible for triggering landslide activity in the Yamuna Basin. 
Landslide occurrence data provides a prospective active tectonic zone in the Himalaya. Nearly $15 \%$ of the landmass in India is susceptible to landslide according to Geological Survey of India and the Himalaya covers maximum vulnerable landmass [24] because of its ongoing tectonic movement. Adverse lithology separated by tectonically and seismically active thrust boundaries in the working process behind this natural hazard. Recently landslide occurrence and susceptibility map of the Yamuna basin has been prepared [24]. It is noticed that density of landslide occurrence is maximum in the north of the RT-BT were many faults such as MT, RT, PT, HT, and BT exist and in the region south of the TT where CT, KT, MBT, and Aglar fault are present in the Yamuna basin (Figure 7(b)).

\section{Discussion \& Conclusion}

Dynamic exchange between endogenic tectonic processes and exogenic erosional processes in landform growth has been discussed since recent time. It is quite impossible to measure the degree of intensity of endogenic tectonic uplift on drainage morphometry with morphotectonic parameters alone. No single variable is sufficient alone to draw a line between the response of landform to tectonic upliftment and climate induced erosion. However, combined with structural settings, annual rainfall and seismic data, these parameters generate a clear picture to the spatial distribution and level of tectonic uplift in Yamuna basin. As the main tributary of the Ganga, Yamuna drains southern slope of Himalaya in its higher ranges. Annual rainfall fluctuation in upper reaches of the basin, increases rainfall erosivity and induce reactivation of these tectonic lineaments which also trigger number of seasonal landslides. Amplified transportation of eroded meta-sedimentary sediments in river channel form the upper reaches take places and the sediments deposit in flood plains of Yamuna. Although rainfall induced reactivation of lineament plays a very minute role or yet to be discovered.

Intensity of deformation varies spatially in imbricated lithological units and it is possibly due to locking-unlocking of the ramp along the MHT in different regions of the Himalaya. Observed morphotectonic indices characterize high to moderate tectonic activity in both the hinterland zone between the MT and RT and the foreland zone between the TT and the MBT. Apart from MT, instability in the northern zone is also initiated by ongoing amplification of the axial zone of the Kharsali window and besides MBT and intense back thrusting of TT in the south, structural control of the Aglar fault on the morphology of the Krol nappe is also remarked by early workers [79]. While the central area between these two active zones is less active which is very similar with early derived normalized channel steepness index [18] (Figure 8(a)). Erosion rate derived by early workers [18], explicitly in sub-basin 2 and 4 (sub-basin \#8 and \#7 respectively in [18]) exhibit maximum erosion rate $4.59 \pm 0.39 \mathrm{~mm} / \mathrm{yr}$ and $1.17 \pm 0.09$ progressively while for sub-basin 11 (sub-basin \#1 in [18]), it is $\sim 0.55 \pm 0.04 \mathrm{~mm} / \mathrm{yr}$. Near MT zone, underlying geometry and architecture of the $\sim 16^{\circ}$ dipping MHT ramp constrain the style of erosion pattern and active tectonic zone because a distinct 

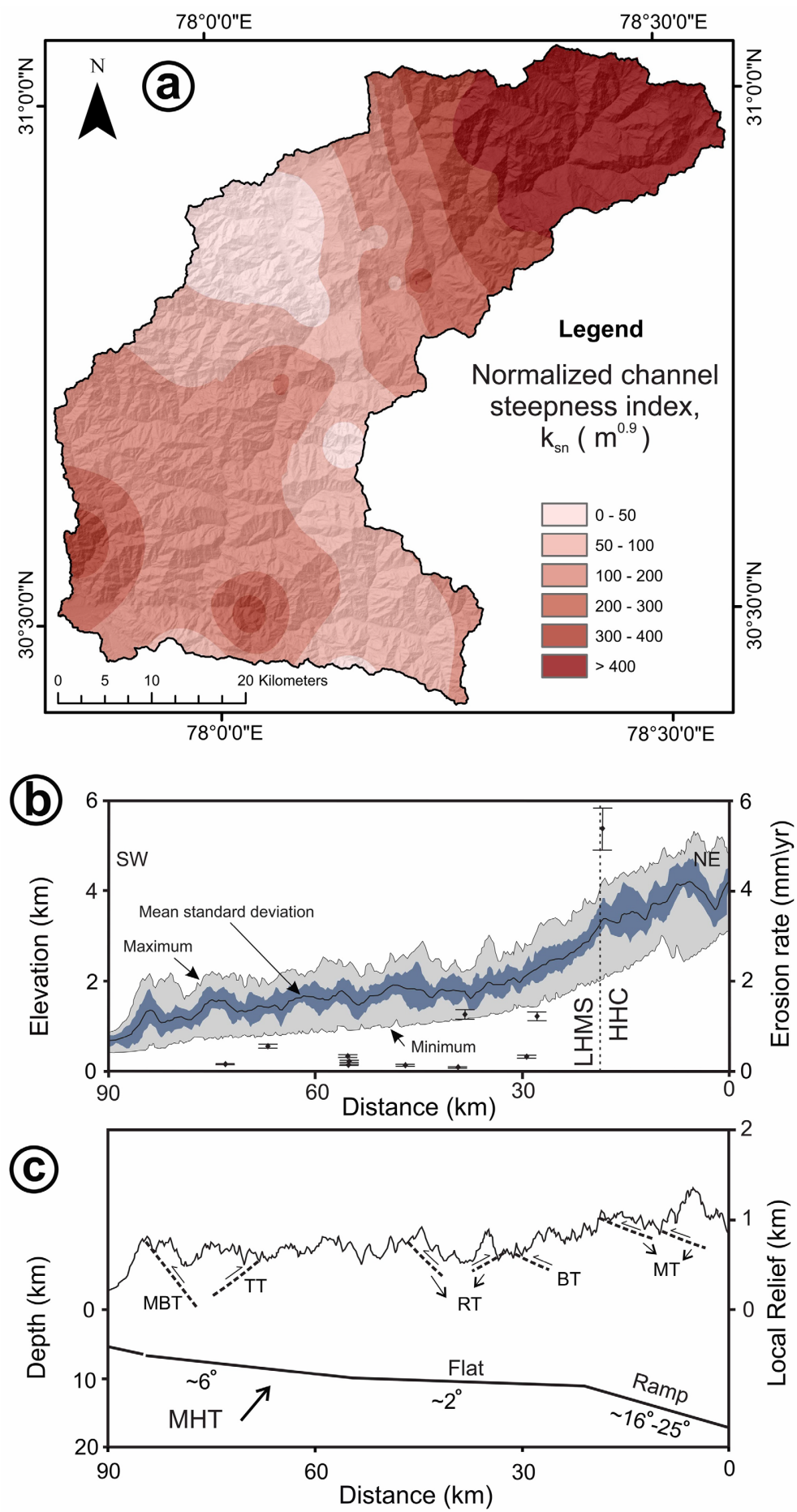

Figure 8. (a) Distribution of normalized steepness index $\left(\mathrm{k}_{\mathrm{sn}}\right)\left(\mathrm{m}^{0.9}\right)$ [18] which is similar with IRAT distribution in Figure $6(b) . k_{s n}$ increases towards north of the Yamuna valley. (b) $40 \mathrm{~km}$ wide swath profile, presenting distribution of elevation in Yamuna valley, Garhwal Himalaya from NE to SW (see Figure 2 for swath profile outline). Plots of erosion rates with vertical error bars. High erosion rate is observed at transition of HHC and LHMS (after [18] [83]). (c) Local relief, major thrust boundaries and subsurface geometry of MHT décollement [18] [58]. (dip angle of thrusts may not correct) for complete name of thrust initials see Figure 1. 
belt of micro-seismic epicenters lying at $\sim 15-20 \mathrm{~km}$ depth along PT2 is typically interpreted as the result of strain accumulation near the creeping/locked transition at depth along a ramp in the MHT [48] [52] [53] [58] [80] [81]. This segment of MHT is accompanied by a maximum upliftment rate of $\sim 4.0-5.7$ $\mathrm{mm} / \mathrm{yr}$ with an average sliding rate of $\sim 14-20 \mathrm{~mm} / \mathrm{yr}$ of the Himalayan orogenic wedge. In further south, Yamuna catchment again gains a relatively higher uplift rate of $\sim 0.37-0.53 \mathrm{~mm} / \mathrm{yr}$ over gently dipping MHT attain a steeper dip of $\sim 6^{\circ}, \sim 18-35 \mathrm{~km}$ north of the MBT with the occurrence of soberly noticeable tremors [18] (Figure 8(b), Figure 8(c)).

Whereas central part of the Yamuna basin (bounded between MT in the north and TT in the south) is characterized by two different tectonic settings. In the north region, synformally folded thrust sheets with the Purola klippe at its core while the southern part is footwall block of the TT with no composite structure as the northern part. Significant low values of SL, Bs, HI and Af are estimated in these sub-basins. The resulted IRAT values in this region indicate moderate to low tectonic activity. Probably emplacement of these thrust sheets along with the Purola klippe and back thrusting along the TT were followed by locking of tectonic movement along local thrusts $\mathrm{HT}, \mathrm{PT}$ and $\mathrm{BT}$. Here, $2^{\circ}$ flat ramp beneath the surface, is associated with the lowest rock uplift rate of $\sim 0.1-0.2 \mathrm{~mm} / \mathrm{yr}$ in this segment [82] with low IRAT and least histories of earthquake. It explains moderate to low activity in central part of Yamuna basin. This must notify that change in numerical values of a certain parameter in different sub-basins with homogeneous lithological settings clarifies that in Himalayan orogenic configuration, lithology has relegate to no control over landscape morphology. All marked small/large-scale landslides trigger by whether seismic or coseismic origin but magnitude-frequency distribution of landslide inference the influence of structural discontinuities in Himalaya. Seismicity in Yamuna valley is comparatively lower than that of the adjacent Alaknanda and Bhagirathi valleys however subsurface geometry is quite uniform throughout Garhwal Himalaya. This heterogeneous seismicity is needs to be explored to reveal the variation in geodynamic evolution on more local scale.

The purpose of research is to explore the dynamics of earth and universe hence it should be related to serving mankind. Yamuna basin also has spiritual and economic importance. Thousands of people visits Yamunotri every year for its religious significance and natural beauty. As well as many government projects are ongoing in this region. Neo-tectonic deformation generates natural hazards and consequently claims many lives. Therefore, this study has established a relatively cohesive approach to classify the areas with seismotectonic format of a region and so can contribute in landslide and seismic hazard mitigation.

\section{Acknowledgements}

We are thankful for Science and Engineering Research Board (SERB), Department of Science and Technology (DST), Govt. of India's research project (No: 
IR/S4/ESF-15/2009) awarded to R.C. Patel to establish this national facility in Fission Track Dating at Department of Geophysics, Kurukshetra University where this work was completed successfully. RCP is also thankful to the Ministry of Earth Sciences (MoES), Govt. of India, for providing support (Project No:

MoES/P.O. (Geo)/101(i)/2017) to complete the research work.

\section{Conflicts of Interest}

The authors declare no conflicts of interest regarding the publication of this paper.

\section{References}

[1] Burbank, D.W., Blythe, A.E., Putkonen, J., Pratt-Sitaula, B., Gabet, E., Oskin, M., Barros, A. and Ojha, T.P. (2003) Decoupling of Erosion and Precipitation in the Himalayas. Nature, 246, 625-655. https://doi.org/10.1038/nature02187

[2] Reiners, W., Ehers, T.A., Mitchell, S.G. and Montgomery, D.R. (2003) Coupled Spatial Variations in Precipitation and Long-Term Erosion Rates across the Washington Cascade. Nature, 426, 645-647. https://doi.org/10.1038/nature02111

[3] Molnar and England (1990) Late Cenozoic Uplift of Mountain Ranges and Global Climatic Change: Chicken or Egg? Nature, 346, 29-34. https://doi.org/10.1038/346029a0

[4] Raymo, M.E. and Ruddiman, W.F. (1992) Tectonic Forcing of Late Cenozoic Climate. Nature, 359, 117-122. https://doi.org/10.1038/359117a0

[5] Chase, C.G. (1992) Fluvial Landsculpting and the Fractal Dimension of Topography. Geomorphology, 5, 39-57. https://doi.org/10.1016/0169-555X(92)90057-U

[6] Montgomery, D.R. and Dietrich, W.E. (1994) A Physical Based Model for the Topographic Control of Shallow Landsliding. Water Resources Research, 30, 1153-1171. https://doi.org/10.1029/93WR02979

[7] Gao, J. and Xia, Z. (1996) Fractals in Physical Geography. Progress in Physical Geography, 20, 178-191. https://doi.org/10.1177/030913339602000204

[8] Pinter, N. and Brandon, M.T. (1997) How Erosion Builds Mountains. Scientific America, 279, 74-79. https://doi.org/10.1038/scientificamerican0497-74

[9] Cox, R.T. (1994) Analysis of Drainage-Basin Symmetry as a Rapid Technique to Identify Areas of Possible Quaternary Tilt-Block Tectonics: An Example from the Mississippi Embayment. Geological Society of America Bulletin, 106, 571-581. https://doi.org/10.1130/0016-7606(1994)106<0571:AODBSA >2.3.CO;2

[10] Keller, E.A. and Pinter, N. (1996) Active Tectonics: Earthquakes, Uplift, and Landscape, 2nd Edition, Prentice Hall, Englewood Cliffs.

[11] Valdiya, K.S. (1995) Proteriozoic Sedimentation and Pan-African Geodynamic Development in the Himalaya. Precambrian Research, 74, 35-55. https://doi.org/10.1016/0301-9268(95)00004-O

[12] Valdiya, K.S. (2003) Reactivation of Himalayan Frontal Fault: Implications. Current Science, 85, 1031-1040. http://www.jstor.org/stable/24108786

[13] Bookhagen, B., Thiede, R.C. and Strecker, M.R. (2005) Late Quaternary Intensified Monsoon Phases Control Landscape Evolution in the Northwest Himalaya. Geology, 33, 149-152. https://doi.org/10.1130/G20982.1

[14] Yin, A. (2006) Cenozoic Tectonic Evolution of Himalaya Orogen as Constrained by 
along Strike Variation of Structural Geometry, Exhumation History, and Foreland Sedimentation. Earth Science Review, 76, 1-131. https://doi.org/10.1016/j.earscirev.2005.05.004

[15] Perez-Pena, J.V., Azanon, J.M., Azor, A., Delgado, J. and Gonzalez-Lodeiro, F. (2009) Spatial Analysis of Stream Power Using GIS: SLk Anomaly Maps. Earth Surface Processes and Landforms, 34, 16-25. https://doi.org/10.1002/esp.1684

[16] Pazzaglia, F.J. (2013) 9.22 Fluvial Terraces. In: Treatise on Geomorphology, Elsevier, Amsterdam, 379-412. https://doi.org/10.1016/B978-0-12-374739-6.00248-7

[17] Joshi, L.M. and Kotlia, B.S. (2015) Neotectonically Triggered Instability around the Palaeolake Regime in Central Kumaun Himalaya, India. Quaternary International, 37, 219-231. https://doi.org/10.1016/j.quaint.2014.10.033

[18] Scherler, D., Bookhagen, B. and Strecker, M.R. (2014) Tectonic Control on 10Be-Derived Erosion Rates in the Garhwal Himalaya, India. Journal of Geophysical Research: Earth Surface, 119, 83-105. https://doi.org/10.1002/2013JF002955

[19] Masek, J.G., Isacks, B.L., Gubbels, T.L. and Fielding, K.J. (1994) Erosion and Tectonics at the Margins of Continental Plateaus. Journal of Geophysical Research, 99, 12,941-13,956. https://doi.org/10.1029/94JB00461

[20] Avouac, J.P. and Burov, E.B. (1996) Erosion as a Driving Mechanism of Intracontinental Mountain Growth. Journal of Geophysical Research-Solid Earth, 101, 17747-17769. https://doi.org/10.1029/96JB01344

[21] Andermann, C. and Gloaguen, R. (2009) Estimation of Erosion in Tectonically Active Orogenies. Example from the Bhatekoshi Catchment, Himalaya (Nepal). International Journal of Remote Sensing, 30, 3075-3096. https://doi.org/10.1080/01431160802558733

[22] Harkins, N.W., Anastasio, D.J. and Pazzaglia, F.J. (2005) Tectonic Geomorphology of the Red Rock Fault, Insights into Segmentation and Landscape Evolution of a Developing Range Front Normal Fault. Journal of Structure Geology, 27, 1925-1939. https://doi.org/10.1016/j.jsg.2005.07.005

[23] Keller, E.A. and Pinter, N. (2002) Active Tectonics: Earthquakes, Uplift, and Landscape. 2nd Edition, Prentice Hall, Upper Saddle River, 362.

[24] Kundu, V. and Patel, R. (2019) Susceptibility Status of Landslides in Yamuna Valley, Uttarakhand, NW-Himalaya, India. Himalayan Geology, 40, 30-49.

[25] Molnar and Tapponier (1975) Ceneozoic Tectonics of Asia; Effects of a Continental Collision. Science, 186, 419-426. https://doi.org/10.1126/science.189.4201.419

[26] DeMets, C., Gordon, R.G., Argus, D.F. and Stein, S. (1994) Effect of Recent Revisions to the Geomagnetic Reversal Time Scale on Estimates of Current Plate Motions. Geophysical Research Letters, 21, 2191-2194.

https://doi.org/10.1029/94GL02118

[27] Banerjee and Burgmann, R. (2002) Convergence across the Northwest Himalaya from GPS Measurement. Geophysical Research Letters, 29, 1652. https://doi.org/10.1029/2002GL015184

[28] Bilham, R., Larson, K., Freymueller, J. and Members, I. (1997) GPS Measurement of Present-Day Convergence across the Nepal Himalaya. Nature, 386, 61-64. https://doi.org/10.1038/386061a0

[29] Patriat, and Achache, J. (1984) Indo-Asia Collision Chronology and Its Implications for Crustal Shortening and Driving Mechanisms of Plates. Nature, 311, 615-621. https://doi.org/10.1038/311615a0

[30] Larson, K.M., Bürgmann, R., Bilham, R. and Freymueller, J.T. (1999) Kinematics of 
the India-Eurasia Collision Zone from GPS Measurements. Journal of Geophysical Research, 104, 1077-1093. https://doi.org/10.1029/1998JB900043

[31] Paul, J., Burgmann, R., Gaur, V.K., Bilham, R., Larson, K.M., Ananda, M.B., Jade, S., Mukul, M., Anupama, T.S., Satyal, G. and Kumar, D. (2001) The Motion and Active Deformation of India. Geophysical Research Letters, 28, 647-650. https://doi.org/10.1029/2000GL011832

[32] Berger, A., Jouanne, F., Hassani, R. and Mugnier, J.L. (2004) Modelling the Spatial Distribution of Present-Day Deformation in Nepal: How Cylindrical Is the Main Himalayan Thrust in Nepal? Geophysical Journal International, 156, 94-114. https://doi.org/10.1111/j.1365-246X.2004.02038.x

[33] Lavé, J. and Avouac, J.P. (2000) Active Folding of Fluvial Terraces across the Siwaliks Hills (Himalayas of Central Nepal). Journal of Geophysical Research, 105, 5735-5770. https://doi.org/10.1029/1999JB900292

[34] Kumar, S., Wesnousky, S.G., Rockwell, T.K., Ragona, D., Thakur, V.C. and Seitz, G.G. (2001) Earthquake Recurrence and Rupture Dynamics of Himalaya Frontal Thrust, India. Science, 294, 2328-2331. https://doi.org/10.1126/science.1066195

[35] Malik, J.N. and Nakata, T. (2003) Active Faults and Related Late Quaternary Deformation along the Northwestern Himalayan Frontal Zone, India. Annales Geophysicae, 46, 917-936.

[36] Mugnier, J.L., Huyghe, L. and Jouanne, F. (2004) Episodicity and Rates of Thrust Sheet Motion in the Himalayas (Western Nepal), In: McClay, K.C., Ed., Thrust Tectonics and Petroleum Systems, AAPG Memoir 82, Tulsa, 91-114.

[37] Lavé, J. and Avouac, J.P. (2001) Fluvial Incision and Tectonic Uplift across the Himalayas of Central Nepal. Journal of Geophysical Research, 106, 26561-26591. https://doi.org/10.1029/2001JB000359

[38] Kumar, S., Wesnousky, S.G., Rockwell, T.K., Briggs, R.W., Thakur, V.C. and Jayangondaperumal, R. (2006) Paleoseismic Evidences of Grate Surface Rupture Earthquakes along the Indian Himalaya. Journal of Geophysical Research, 111, B03304. https://doi.org/10.1029/2004JB003309

[39] Kumar, S., Wesnousky, S.G., Jayangondaperumal, R., Nakata, T., Kumahara, Y. and Singh, V. (2010) Paleoseismological Evidence of Surface Faulting along the Northeastern Himalayan Front, India: Timming, Size and Spatial Extent of Great Earthquakes. Journal of Geophysical Research, 115, B12422.

https://doi.org/10.1029/2009JB006789

[40] Srivastava and Mitra, G. (1994) Thrust Geometries and Deep Structure of the Outer and Lesser Himalaya, Kumaon and Garhwal (India): Implications for Evolution of the Himalayan Fold-and-Thrust Belt. Tectonics, 13, 89-109.

https://doi.org/10.1029/93TC01130

[41] Biyani, A.K. (1998) A Study of Inverted Matamorphism in the Higher Himalaya Yamuna Valley, Uttarkashi District U.P., India. Journal Geological Society of India, 51, 609-618.

[42] Ahmad, T., Mukherjee, K. and Trivedi, J.R. (1999) Geochemistry of Precambrian Mafic Magmatic Rocks of the Western Himalaya, India: Petrogenetic and Tectonic Implications. Chemical Geology, 160, 103-119. https://doi.org/10.1016/S0009-2541(99)00063-7

[43] Célérier, J., Harrison, T.M., Yin, A. and Webb, A.A.G. (2009) The Kumaun and Garhwal Lesser Himalaya, India. Part 1: Structure and Stratigraphy. Geological Society of America Bulletin, 121, 1262-1280. https://doi.org/10.1130/B26344.1

[44] Burchfiel, B.C., Zhiliang, C., Hodges, K.V., Yuping, L., Royden, L.H., Changrong, D. 
and Jiene, X. (1992) The South Tibetan Detachment System, Himalayan Orogen: Extension Contemporaneous with and Parallel to Shortening in a Collisional Mountain Belt. Geological Society of America Special Paper, 269, 1-41. https://doi.org/10.1130/SPE269-p1

[45] Hérail, G. and Mascle, G. (1980) Les Siwaliks du Nepal central: Structures et gromorphologie d'un pirmont en cours de drformation. Bulletin de P Association de Géographes Français Année, 470-471, 259-267.

https://doi.org/10.3406/bagf.1980.5190

[46] Schelling, D. and Arita, K. (1991) Thrust Tectonics, Crustal Shortening, and the Structure of the Far Eastern Nepal Himalaya. Tectonics, 10, 851-862. https://doi.org/10.1029/91TC01011

[47] Schelling, D. (1992) The Tectonostratigraphy and Structure of Eastern Nepal Himalaya. Tectonics, 11, 5. https://doi.org/10.1029/92TC00213

[48] Pandey, M.R., Tandukar, R.P., Avouac, J.P., Lavé, J. and Massot, J.P. (1995) Interseismic Strain Accumulation on the Himalayan Crustal Ramp (Nepal). Geophysical Research Letters, 22, 751-754. https://doi.org/10.1029/94GL02971

[49] Valdiya, K.S. (1980) Geology of Kumaun Lesser Himalaya, Interim Record. Wadia Institute of Himalayan Geology, Dehradun.

[50] Davidson, C., Grujic, D.E., Hollister, L.S. and Schmid, S.M. (1997) Metamorphic Reaction Related to Decompression and Synkinematic Intrusion of Leucogranite, High Himalayan Crystallines, Bhutan. Journal of Metamorphic Geology, 15, 593-612. https://doi.org/10.1111/j.1525-1314.1997.tb00638.x

[51] Kayal, J.R. (2003) Seismotectonic Structure of the Western and Eastern Himalayas: Constrain from Micro-Earthquake Data. Memoir, Geological Society of India, 53, 279-311.

[52] Caldwell, W.B., Klemperer, S.L., Lawrence, J.F. and Rai, S.S. (2013) Characterizing the Main Himalayan Thrust in the Garhwal Himalaya, India with Receiver Function. Earth and Planetary Science Letters, 367, 15-27. https://doi.org/10.1016/j.epsl.2013.02.009

[53] Mahesh,, Rai, S.S., Sivaram, K., Paul, A., Gupta, S., Sarma, R. and Gaur, V.K. (2013) One-Dimensional Reference Velocity Model and Precise Locations of Earthquake Hypocentres in the Kumaun-Garhwal Himalaya. Bulletin of Seismological Society of America, 103, 328-339. https://doi.org/10.1785/0120110328

[54] Mahesh,, Gupta, S., Utpal, S. and Rai, S.S. (2015) Sesismotectonics and Crustal Stress Field in the Kumaun-Garhwal Himalaya. Tectonophysics, 655, 124-138. https://doi.org/10.1016/j.tecto.2015.05.016

[55] Morell, K.D., Regalla, C., Leonard, L.J., Amos, C. and Levson, V. (2017) Quaternary Rupture of a Crustal Fault beneath Victoria, Brithish Columbia, Canada. Geological Society of America, 27, 4-10. https://doi.org/10.1130/GSATG291A.1

[56] Negi, S.S., Paul, A., Cesca, S., Kriegerowski, M., Mahesh and Gupta, S. (2017) Crustal Velocity Structure and Earthquake Processes of Garhwal-Kumaun Himalaya: Constraints from Regional Waveform Inversion and Array Beam Modeling. Tectonophysics, 712-713, 45-63. https://doi.org/10.1016/j.tecto.2017.05.007

[57] Dumka, R.K., Kotlia, B.S., Kothyari, G.C., Palkrey, J. and Dimri, S. (2018) Detection of High and Moderate Crustal Strain Zones in Uttrakhand Himalaya, India. Acta Geodaetica Et Geophysica, 53, 503-521. https://doi.org/10.1007/s40328-018-0226-Z

[58] Patel, R.C., Manmohan, Karnwal, R. and Kumar, R. (2019) Tectonic Control on Exhumation and Seismicity in the Garhwal-Kumaun Himalaya, NW-India. Tera Nova, 32, 23-33. https://doi.org/10.1111/ter.12432 
[59] Patel, R.C., Kumar, Y., Lal, N. and Kumar, A. (2007) Thermotectonic History of the Chiplakot Crystalline Belt in the Lesser Himalaya, Kumaun, India: Constraints from Apatite Fission-Track Thermochronology. Journal of Asian Earth Science, 29, 430-439. https://doi.org/10.1016/j.jseaes.2006.04.008

[60] Patel, R.C. and Carter, A. (2009) Exhumation History of the Higher Himalayan Crystalline along Dhauliganga-Goriganga River Valleys, NW India: New Constraints from Fission-Track Analysis. Tectonics, 28, TC3004. https://doi.org/10.1029/2008TC002373

[61] Singh,, Patel, R.C. and Lal, N. (2012) Plio-Plistocene In-Sequence Thrust Propagation along the Main Central Thrust Zone (Kumaun-Garhwal Himalaya, India): New Thermochronological Data. Tectonophysics, 574, 193-203. https://doi.org/10.1016/j.tecto.2012.08.015

[62] Patel, R.C., Singh, and Lal, N. (2015) Thrusting and Back-Thrusting as PostEmplacement Kinematics of the Almora Klippe: Insights from Low-Temperature Thermochronology. Tectonophysics, 653, 41-51. https://doi.org/10.1016/j.tecto.2015.03.025

[63] Lemonnier, C., Marquis, G., Perrier, F., Avouac, J.P., Chitrakar, G., Kafle, B., Sapkota, S., Gautam, U., Tiwari, D. and Bano, M. (1999) Electrical Structure of the Himalaya of Central Nepal: High Conductivity around the Mid-Crustal Ramp along the MHT. Geophysical Research Letters, 26, 3261-3264.

https://doi.org/10.1029/1999GL008363

[64] Robert, X., van der Beek, Braun, J., Perry, C. and Mugnier, J.L. (2011) Control of Detachment Geometry on Lateral Variations in Exhumation Rates in the Himalaya: Insights from Low-Temperature Thermochronology and Numerical Modeling. Journal of Geophysical Research, 116, B05202.

https://doi.org/10.1029/2010JB007893

[65] Wobus, C.W., Whipple, K.X. and Hodges, K.V. (2006) Neotectonics of the Central Nepalese Himalaya: Constraints from Geomorphology, Detrital 40Ar/39Ar Thermochronology, and Thermal Modeling. Tectonics, 25, TC4011. https://doi.org/10.1029/2005TC001935

[66] Morell, K.D., Sandiford, M., Rajendran, C.P., Rajendran, K., Alimanovic, A., Fink, D. and Sanwal, J. (2015) Geomorphology Reveals Active Décollement Geometry in the Central Himalayan Seismic Gap. Lithosphere, 7, 247-256.

https://doi.org/10.1130/L407.1

[67] Cattin, R. and Avouac, J.P. (2000) Modeling Mountain Building and the Seismic Cycle in the Himalaya of Nepal. Journal of Geophysical Research, 105, 13,389-13,407. https://doi.org/10.1029/2000JB900032

[68] Whipple, K., Shirzaei, M., Hodges, K. and Arrowsmith, R. (2016) Active Shortening within the Himalayan Orogenic Wedge Implied by the 2015 Gorkha Earthquake. Nature Geoscience, 9, 711-716. https://doi.org/10.1038/ngeo2797

[69] Robert, X., Van der Beek,, Braun, J., Perry, C., Dubille, M. and Mugnier, J.L. (2009) Assessing Quaternary Reactivation of the Main Central Thrust Zone (Central Nepal Himalaya): New thermochronologic Data and Numerical Modeling. Geology, 37, 731-734. https://doi.org/10.1130/G25736A.1

[70] Herman, F., Copeland,, Avouac, J.P., Bollinger, L., Mahéo, G., Le Fort, and Henry, (2010) Exhumation, Crustal Deformation, and Thermal Structure of the Nepal Himalaya Derived from the Inversion of Thermochronological and Thermobarometric Data and Modeling of the Topography. Journal of Geophysical Research, 115, B06407. https://doi.org/10.1029/2008JB006126 
[71] Strahler, A.N. (1957) Quantitavie Analysis of Watershade Geomorphology. Transactions of the American Geophysical Union, 38, 913-920. https://doi.org/10.1029/TR038i006p00913

[72] Sharma, G., Champatiray, K. and Mohanty, S. (2018) Morphotectonic Analysis and GNSS Observation for Assessment of Relative Tectonic Activity in Alaknanda Basin of Garhwal Himalaya. Geomorphology, 301, 108-120. https://doi.org/10.1016/j.geomorph.2017.11.002

[73] Keller, E.A. (1986) Investigation of Active Tectonics: Use of Surficial Earth Processes, Active Tectonics. National Academy Press, Washington DC, 136-147.

[74] Jade, S. (2004) Estimates of Plate Velocity and Crustal Deformation in Indian Subcontinent Using GPS Geodesy. Current Science, 86, 1443-1448.

[75] Kanaujia, J., Kumar, A. and Gupta, S.C. (2015) 1D Velocity Structure and Charactersics of Contemporary Local Seismicity around the Tehri Region, Garhwal Himalaya. Bulletin Seismic Society of America, 105, 1852-1869. https://doi.org/10.1785/0120140306

[76] Anbalagan, R. and Singh, B. (1996) Landslide Hazard and Risk Assessment Mapping of Mountainous Terrains-A Case Study from Kumaun Himalaya, India. Engineering Geology, 43, 237-246. https://doi.org/10.1016/S0013-7952(96)00033-6

[77] Sarkar, S., Kanungo, D.P. and Patra, A.K. (2005) Landslides in Alaknanda Valley of Garhwal Himalaya, India. Quarterly Journal of Engineering Geology \& Hydrogeology, 39, 79-142. https://doi.org/10.1144/1470-9236/05-020

[78] Mahmood, S.A. and Gloaguen, R. (2012) Appraisal of Active Tectonics in Hindu Kush: Insights from DEM Derived Geomorphic Indices and Drainage Analysis. Geoscience Frontier, 3, 407-428. https://doi.org/10.1016/j.gsf.2011.12.002

[79] Bhatta, S., Biyani, A. and Dudeja, D. (2012) Morphometric Analysis of Drainage Basins in Lakhwar and Adjoining Areas of Dehradun and Tehri Garhwal Districts, Uttarakhand, India. Journal of Nepal Geological Society, 37, 45-54.

[80] Harvey, E.J., Burbunk, D.W. and Bookhagen, B. (2015) Along-Strike Changes in Himalayan Thrust Geometry: Topographic and Tectonic Discontinuities in Western Nepal. Lithosphere, 7, 511-518. https://doi.org/10.1130/L444.1

[81] Elliott, J., Joliet, R., Gonzalez, J., Avouce, J.P., Hollingsworth, J., Searle, M.P. and Stevens, V.L. (2016) Himalayan Megathrust Geometry and Relation to Topography Revealed by the Gorkha Earthquake. Nature Geoscience, 9, 174-180. https://doi.org/10.1038/ngeo2623

[82] Kanaujia, J., Kumar, A. and Gupta, S.C. (2016) 13-D Velocity Structure around Tehri Region of the Garhwal Lesser Himalaya: Constrain on Geometry of the Underthrusting Indian Plate. Geophysical Journal International, 205, 900-914. https://doi.org/10.1093/gji/ggw056

[83] Olen, S.M., Bookhagen, B. and Strecker, M.R. (2016) Role of Climate and Vegetation Density in Modulating Denudation Rates in the Himalaya. Earth and Planetary Science Letters, 445, 57-67. https://doi.org/10.1016/j.epsl.2016.03.047 